\title{
ISLAMIC BANKING: REgULATORY BACKGROUND from the Czech Perspective
}

\author{
Jakub Vojtěch ${ }^{1}$
}

\section{Faculty of Law, Charles University in Prague, Czech Republic email: Jakub.Vojtech@seznam.cz}

VOJTĚCH, Jakub. Islamic Banking: Regulatory Background from the Czech Perspective. International and Comparative Law Review, 2015, vol. 15, no. 2, pp. 123-134. DOI: 10.1515/iclr-2016-0039.

\begin{abstract}
The term "Islamic banking" denotes the banking services in compliance with Islamic law and is nowadays a rapidly expanding, global industry based on a traditional fourteen centuries old legal system. The European market is witnessing growing Shariacompliant assets especially in the last few years and even non-Muslim countries have been trying to find legal solutions to accomodate Islamic financial institutions. This new academic and business field is raising important issues that merit discussion and this text serves as a contribution to the debate. In the paper I am trying to depict the key and distinguishing features of the Islamic banking model and reflect its law regulation from the point of view of the Czech legislation in the light of the continuing growth and expansion of Islamic banking and finance. The main objective of this article is to find out whether the legal framework of the Czech Republic covers the practice of Islamic finance and also to consider and identify potential legal obstacles.
\end{abstract}

Keywords: Islam; banks; Sharia; Czech Republic; Murabaha; Mudaraba; deposits; Czech National Bank; deposit guarantee scheme.

\section{An alternative to conventional banking?}

In September $2010,{ }^{2}$ the International Monetary Fund (IMF) released a study ${ }^{3}$ comparing the performance of Islamic banks and conventional banks during the recent financial crisis, and found that Islamic banks, on average, showed stronger resilience during the global financial crisis. Islamic finance is one of the fastest growing segments of the global financial industry. In some countries, it has become systematically important and, in many others, it is too big to be ignored.

1 Ph.D. student at Charles University in Prague, Faculty of Law, Department of Financial Law and Financial Science, Czech Republic; email: Jakub.Vojtech@seznam.cz

2 This paper has been elaborated with a financial support from the project "Perspectives of development of financial law in the Czech Republic and the European Union" within the framework of the Specific University Research no. 260 136/2015 which is realized at the Faculty of Law of the Charles University in Prague in the year 2015.

3 International Monetary Fund. The Effects of the Global Crisis on Islamic and Conventional Banks: A Comparative Study [online]. IMF, c2010 [24.10.2015]. Accessbile from WWW: $<$ http://www.imf.org/external/pubs/ft/wp/2010/wp10201.pdf>. 
Today, the largest Islamic banks are located in the countries of the Gulf Cooperation Council (Bahrain, Kuwait, Oman, Qatar, Saudi Arabia, and the United Arab Emirates). ${ }^{4}$

The recent recession that affected the world economy as a whole revived the discussion on whether there is a suitable and viable alternative to the current methods of providing financial services based on ethical principles in the financial sector and how to implement ethical values into the banking business. The reason why Islamic institutions escaped the crisis relatively unscathed according to the IMF study is quite simple. Because many of the conventional practices that caused the financial freeze could ever pass through an approval process of any Islamic bank's Sharia Supervisory Board. Indeed, neither the securitization of subprime loans (which is a sale of debt) nor credit default swaps (which are the sale of promises and are rife with gharar) are acceptable. ${ }^{5}$

The global demand for Islamic products is difficult to quantify, but during the recently held 10th annual meeting of the World Islamic Economic Forum 2015 in Dubai it was predicted that the global Islamic economy will double to be worth $\$ 3.4$ trillion in the next four years, and shown that the sukuk (Islamic bond) market is growing by more than 10 percent a year. Because of this emerging strength, the global Islamic finance industry has moved into the mainstream of global business that no world business hub can ignore. The wider acceptance of the benefits of Islamic finance can be illustrated by how several non-Muslim countries have raised finance by using sukuks. Singapore, Hong Kong and the UK have all successfully raised money by issuing sukuks. ${ }^{6}$

This growing popularity is further supported by 57 Muslim countries ${ }^{7}$ in the world. Here it's necessary to point out that $1 / 3$ of all Muslims represent a minority population ${ }^{8}$ (although sometimes very numerous) in their country of residence. That is one and a half billion people, which means every fifth person on this planet ${ }^{9}$.This data might reflect an interesting market potential for

4 International Monetary Fund. Islamic Banks: More Resilient to Crisis? [online]. IMF, c2010 [25.10.2015]. Accessible from WWW: <http://www.imf.org/external/pubs/ft/survey/ so/2010/res100410a.htm>.

5 NETHERCOTT, Craig R; EISENBERG David M. Islamic finance: law and practice. Oxford: Oxford University Press, 2012, p. 13. ISBN 978-0-19-956694-5.

6 MATTHEW, Francis. Dubai uses its position as a global hub to promote Islamic economy. Gulfnews.com [online]. c2014 [24.10.2015]. Accessible from WWW: <http://gulfnews. com/opinions/columnists/dubai-uses-its-position-as-a-global-hub-to-promote-islamiceconomy-1.1405752>.

7 Organization of the Islamic Conference. Member States [online]. OIC, c2014 [24.10.2015]. Accessbile from WWW: <http://www.oic-oci.org/oicv2/states/ $>$.

8 EHTESHAMI, Anoushiravan. Islam as a political force in international politics. In LAHOUD, Nelly et al. (ed.). Islam in world politics. 1. publ. New York: RoutledgeCurzon, 2005, p. 37-38. ISBN 0415362679.

9 HALLAQ, Wael B. An Introduction to Islamic Law. Cambridge: Cambridge University Press, 2009, p. 1. ISBN 978-0521678735. 
Islamic banks or other companies with a different scope of business seeking to halalize (to make halal) their products in order to gain new customers. ${ }^{10}$

\subsection{Basic features of Islamic banks}

While Islamic banks play roles similar to conventional banks, fundamental differences exist between the two models. The main distinction between Islamic and conventional banks is that the former operate in accordance with the rules of Shari'a, the legal code of Islam. The central concept in Islamic banking and finance is justice, which is achieved mainly through the sharing of risk (Shiraka). Stakeholders are supposed to share profits and losses, charging interest is prohibited. ${ }^{11}$

Altogether, it is an entirely different banking system built on totally divergent philosophical postulates related to respecting the precepts of Islamic law. The moral imperatives consist namely in avoiding Haram (prohibited products and activities like alcohol, pork, porn etc.), Riba (interest or increase), excessive risk (Gharar), as well as ban on speculative transactions and gambling (Maysir). Islamic financial institutions embrace the principle of sharing profit and loss (Shiraka) and reject interest as a cost for accepting and lending money. Within these constraints services of Islamic commercial banking are offered relying on Sharia-compliant contracts approved by a specialized (Sharia) Supervisory Board entrusted with the duty of directing, reviewing and supervising the bank's activities to ensure compliance with Islamic values and principles. ${ }^{12}$

\subsection{Islamic financing}

All Islamic contracts applied in the banking field are built on the legal and economic postulates of Islam that include fairness, socio-economic justice, and the principle of "real-asset-based“ transactions and financial instruments. ${ }^{13}$ Unlike in the conventional system where the bank pays interest for the received funds that are just lent at a higher interest rate to someone else, the Islamic doctrine relies on the idea of "no risk, no gain “ implying that if someone wishes to multiply his assets (which is a virtuous act in Islam), then he must undertake adequate efforts and eventually take responsibility for the losses incurred. Hence, although the religion prohibits interest, trading is allowed (the prophet Moham-

10 MAURER, Bill. Re-formatting the Economy: Islamic banking and finance in world politics. In LAHOUD, Nelly et al. (ed.). Islam in world politics. 1. publ. New York: RoutledgeCurzon, 2005, p. 62. ISBN 0415362679.

11 International Monetary Fund. Islamic Banks: More Resilient to Crisis? [online]. IMF, c2010 [24.10.2015]. Accessible from WWW: <http://www.imf.org/external/pubs/ft/survey/ so/2010/res100410a.htm>.

12 NETHERCOTT, Craig R; EISENBERG David M. Islamic finance: law and practice. Oxford: Oxford University Press, 2012, p. 55. ISBN 978-0-19-956694-5.

13 AYUB, Muhammad. Understanding Islamic finance. Hoboken, NJ: John Wiley, c2007, p. 13. ISBN 978-047-0030-691. 
mad was a merchant himself) and profit as a return from business activities is allowed. ${ }^{14}$

The preferred models of financing in Islam are „equity-based“ which include investment partnerships (Shiraka) in the form of Mudaraba or Musharaka. Additionally, the „debt-based“ model of financing called Murabaha („credit sale with markup") and the leasing contract Ijara ("lease-to-purchase") are also widely used and accepted.

\subsection{Examples of Islamic banking contracts}

Murabaha (sale on credit for a term) is the most popular and most common form of financing under Sharia. As a financing technique, it involves a request by the client to the bank to purchase a certain item for him. The bank does that for a definite profit over the cost which is settled in advance. In fact Murabaha consists of two sales contracts: the first one between the owner of goods and the bank, and the second between the bank and its client for the sale of goods at a price plus an agreed profit margin for the bank. So it involves the purchase of goods by the bank in the first step which then re-sells them to the client at an agreed mark-up. Repayment is usually in installments. ${ }^{15}$

From the economic point of view such a financing operation usually equals to (interest bearing) conventional loan. But considering the fact that we talk about a purchase agreement and that trading is supported in Islam, therefore from the legal perspective are met the requirements contained in the famous Qur'anic verse 275 of the Surat Al-Baqara: „...but Allah hath permitted trade and forbidden usury "16. Nevertheless, some scholars have raised questions concerning the lawfulness of Murabaha because it involves aspects that resemble interest since some Islamic banks are often benchmarking their profit margin to LIBOR.

As another example of Islamic financing could be mentioned the Mudaraba contract that is based on a partnership in which one partner is the financier (the investor, or silent partner) and the other partner (the fund manager, or working partner) manages the financier's investment in an economic activity. The second partner (often an entrepreneur) has expertise in applying the venture capital into the economic activities. Both parties agree in advance to a profit - and loss-sharing (PLS) ratio, any loss affects only the investor. Mudaraba contracts can also serve as a source of funds for an Islamic bank. When customers deposit money

14 KÕVE, Anu. Current and Savings Deposits in Conventional and Islamic Retail Banking in the EU [online]. juridicainternational.eu, c2011 [24.10.2015]. Accessible from WWW: $<$ http://www.juridicainternational.eu/index.php?id=14831 $>$.

15 Institute of Islamic banking and insurance. Murabaha on Shariah Ruling [online]. islamicbanking.com, [24.10.2015]. Accessible from WWW: <http://www.islamic-banking.com/ murabaha_sruling.aspx $>$.

16 ALI, Abdullah Yusuf. The meaning of the Holy Qu'ran. 11th ed. Beltsville, MD: Amana Publications, 2004, p. 115. ISBN 1590080262.

\section{(C) Palacký University Olomouc, Czech Republic, 2015. ISSN 1213-8770 (print), ISSN: 2464-6601 (online).}


and expect a return, they're the investors (exclusively bearing the loss if any) and the bank is the fund manager or working partner that invests the depositors' money according to Sharia guidelines. ${ }^{17}$ Any kind of previous guarantees concerning the expected future returns is strictly prohibited.

\section{Legal groundwork for the practice of Islamic banking}

The European market is witnessing growing Sharia-compliant assets especially in the last few years and we can observe that many countries have been trying to find a solution to accomodate the Islamic financial institutions. The growing Muslim population in Europe might be one of the reasons, leading to significant opportunities for entrepreneurs and investments. ${ }^{18}$ On the following pages my main objective is to find out whether the legal framework of the Czech Republic covers the practice of Islamic finance, and to consider and identify potential legal obstacles in Czech legislation from the point of view of Islamic banking services.

\subsection{Islam and banking in the Czech Republic: current situation}

Despite the fact that there are almost 50 entities operating as a bank in the Czech Republic ${ }^{19}$ (most of them being banks from other EU-countries that are making use of the European single banking license valid throughout all 28 member states of the Union), none of them can be classified as an Islamic bank or an institution offering at least some of the Islamic banking services through the "Islamic window" model. However, some of these institutions do provide Islamic services to their clients elsewhere in the world (e.g. Citibank).

First of all, there cannot be perceived apparently any pressure of the Czech customers on the banking institutions present at this central European market to offer any religiously based services. The Muslim community in the Czech Republic is numerically negligible compared with that of France, Germany or the UK for example. According to the Interior Ministry 11,235 Muslims are living in the country and form about 0.1 percent of the population of 10.5 million people, compared with 7.5 percent in France. The survey has found that not only

17 JAMALDEEN, Faleel. The Mudaraba Contract in Islamic Finance. Islamic Finance For Dummies [online]. [25.10.2015]. Accessible from WWW: <http://www.dummies.com/ how-to/content/the-mudaraba-contract-in-islamic-finance.html>.

18 HRDLICKOVA, Ivana. Legal Groundwork for the Practice of Islamic Finance in Central Europe [online]. hrdlickova.com, c2012 [20.10.2015]. Accessible from WWW: <http:// www.hrdlickova.com/files/2012-legal-groundwork-for-the-practice-of-islamic-finance. pdf $>$. Similar opinion is mentioned here: ROHE, Mathias. Das islamische Recht: Geschichte und Gegenwart. 2., durchgesehene Auflage, München: C. H. Beck, 2009, p. 374. ISBN 9783-406-57955-4.

19 Czech National Bank. General summary of the number of entities as of a selected date [online]. CNB.cz, c2015 [20.10.2015]. Accessible from WWW: <https://apl.cnb.cz/ apljerrsdad/JERRS.WEB24.SUBJECTS_COUNTS?p_lang=en>. 
is the Muslim population miniscule but an absolute majority rejects fanaticism, does not seek Sharia and has no problem living in a secular country. ${ }^{20}$

Here it is necessary to point out that based on some estimates the country has even one of the least religious populations in the world, being the country with the third most atheistic population by percentage, behind only China and Japan. ${ }^{21}$ According to the 2010 census, the number of people who listed their religion as „Knights of the Jedi“ (warriors of the „Star Wars“ films) actually exceeds that of the Muslims living in the country. ${ }^{22}$

After mentioning some hard data above it may appear that this central European country is way too far from implementing Sharia banking standards in the short term. Nevertheless, entrance of an Islamic bank in the long term cannot be excluded especially taking into account the ongoing immigration crisis in the EU mostly from Muslim states. Very significant are also efforts of the Czech government made to create a highly open financial system in the past few years (especially by reforming the regulatory environment: Act No. 89/2012 Coll., New Civil Code; Act No. 90/2012 Coll., on Commercial Companies and Cooperatives; Act No. 240/2013 Coll., on Management Companies and Investment Funds etc.) following the example of the Netherlands and Ireland. Islamic banking might also help boost Czech exports into Muslim countries. ${ }^{23}$

\subsection{Czech regulatory limitations}

Starting with the basic requirements for the functioning of any Islamic bank (Halal, Riba, Gharar, Maysir, Shiraka, Sharia Board) mentioned above and various types of products offered by such a bank, there might arise some regulatory barriers or - at least - handicaps (compared to the conventional banks) in the current Czech legal order.

\subsubsection{Sharia as a non-state legal system}

The first problem lies in the character of Islamic law itself which is not a codified legal system, so that according to some authors ${ }^{24}$ is not acceptable to determine Islamic law as the law governing a contract. Even based on dominant

20 Czech News Agency. Czech Muslims are numerically negligible [online]. Praguepost, c2015 [20.10.2015]. Accessible from WWW: <http://www.praguepost.com/czech-news/43767czech-muslims-are-numerically-negligible $>$.

21 Wikipedia. Czech Republic. Religion [online]. wikipedia, c2015 [20.10.2015]. Accessible from WWW: <https://en.wikipedia.org/wiki/Czech_Republic >.

22 LINCOLN, Kevin. 15,000 People In The Czech Republic Say Their Religion Is 'Knights Of The Jedi' [online]. businessinsider, c2011 [20.10.2015]. Accessible from WWW: <http://www. businessinsider.com/czech-republic-jedi-2011-12>.

23 RICHTER, Jan. Can Islamic banking help boost Czech exports? [online]. Radio.cz, c2012 [21.10.2015]. Accessible from WWW: <http://www.radio.cz/en/section/marketplace/canislamic-banking-help-boost-czech-exports $>$.

24 ROHE, Mathias. Das islamische Recht: Geschichte und Gegenwart. 2., durchgesehene Auflage, München: C. H. Beck, 2009, p. 374. ISBN 978-3-406-57955-4. 
voices in the Czech legal theory ${ }^{25}$ and text of section 87 (1) of Act No. 91/2012 Coll., on Private International Law ${ }^{26}$, must be the term „applicable law“ contained in this provision interpreted as meaning "state law". This implicates that it is not allowed to choose a non-state law which means that the institute of choice of law in the Islamic finance contracts has a limited impact.

Also the well-known UK precedent delivered in the case of Shamil Bank of Bahrain v. Beximco Pharmaceutical in 2004, said that non-state law is not allowed in the contract. The dispute arose out of two financing agreements (styled as Sharia-compliant) between an Islamic bank and two of the defendants that defaulted on their obligations and sought to avoid their enforcement on the ground that the agreements were for interest-bearing loans. Therefore invalid under Sharia, which categorically prohibits the payment and collection of interest. This argument might have been successful had Sharia applied. ${ }^{27}$

This means that from the contractual perspective any Islamic finance contract must rely on a detailed wording. That's not factually posing any significant inconvenience because even the Czech conventional banks are offering their clients standard form contracts with reference to extremely detailed Terms and Conditions that usually differ from the non-compulsory provisions of the Czech law.

\subsubsection{Business model of Islamic banks}

Second, under the current legal circumstances it's also highly questionable if any Islamic bank could even be licensed by the Czech National Bank (CNB). Although the applicable Czech legislation has no ambition to impose some specific business model on the commercial banks, however, their business plan must be approved by the central bank as one of the conditions of issuance of the license as is specified by section 4 (5) (g) of Act No. 21/1992 Coll., on Banks ${ }^{28}$, according to which for the licence to be granted "the bank must have a programme of operations proceeding from its proposed strategy of activities and based on realistic economic calculations" and the provision 25c (3) (i) states that the CNB exercises review and evaluation focusing on ,the business model of the bank".

25 See (Czech) commentary to this section In PAUKNEROVA, Monika; ROZEHNALOVA, Naděžda; ZAVADILOVA, Marta. Zákon o mezinárodním právu soukromém: komentár̆. Vyd. 1. Praha: Wolters Kluwer ČR, 2013. ISBN 978-80-7478-368-5.

26 An unofficial translation into English is to be found at the following link: $<\mathrm{http}: / / \mathrm{www}$. czechlegislation.com/en/91-2012-sb $>$.

27 ABDELHADY, Hdeel. Islamic Law in Secular Courts (Again) [online]. Americanbar.com, c2010 [20.10.2015]. Accessible from WWW: <http://www.americanbar.org/content/newsletter/publications/gp_solo_magazine_home/gp_solo_magazine_index/solo_lawyer_ international_islamic_british_sharia_jivraj_hashwani_musawi_beximco_shamil.html $>$.

28 An unofficial translation into English is to be found at the following link: $<$ http://www.cnb. $\mathrm{cz} / \mathrm{en} /$ legislation/acts/download/act_on_banks.pdf>. 
The practice of Islamic finance is proving its profitability in other countries, so just a mere difference in functioning of Islamic banks compared to the conventional industry should not pose per se any reasonable limits which was confirmed by number of experts at the conference held in 2012 at the headquarters of the CNB in Prague. Unfortunately, the central bank's officials refused to share their view on the Islamic banking model itself. ${ }^{29}$

\subsubsection{Two obligatory fields of banking business}

Third, the banking license authorizes under the Czech law any bank (jointstock company having its registered office established in the Czech Republic or a foreign bank having a branch in the country) which has been granted a banking licence to "accept deposits from the public" and to "provide loans ${ }^{\text {"30 }}$. Here we encounter a problem resulting from the legal definitions of a deposit in this Act that shall mean „any funds entrusted to the bank that constitute an obligation of the bank to the depositor to repayment thereof " and of a loan meaning "funds in any form provided temporarily". You can say anything about functioning of an Islamic bank but one thing is sure - its services are not based on depositing or temporal provision of funds. An Islamic bank actually does offer temporary interest-free loans (qard hasan) out of charitable reasons but that is not representative at all for its business model. The bank rather acts as a businessman and is trading with goods (not money) that is sold or leased and from which the bank generates profit (in the form of a „provision“, „fee“, or „rent") or in the position of a business partner participates on real investments sharing gains (or possible losses) of such transactions.

However, the valid and effective legislation is prescribing to the banks to carry on obligatorily these two main banking activities (accepting deposits from the public and providing loans) referred to in paragraphs a) and b). Based on section 34 (2) (a) of Act No. 21/1992 Coll., on Banks, to the bank concerned might be its license withdrawn if it does not accept deposits from the public or provide loans for a period of 6 months.

\subsubsection{Tax implications}

From a tax perspective on the Islamic banking contract of Murabaha, which basically consists of two consecutive sales contracts, the trouble lies in the time gap between these two transactions during which the bank owns the object of purchase for a legal microsecond. If real property will be subject to such a way of financing, basically an obligation arises to pay twice the real estate tranfser tax pursuant to the Statutory Measure of the Senate No. 340/2013 Coll., on Tax on Acquisition of Immovable Property.

29 RICHTER, Jan. Can Islamic banking help boost Czech exports? [online]. Radio.cz, c2012 [21.10.2015]. Accessible from WWW: <http://www.radio.cz/en/section/marketplace/canislamic-banking-help-boost-czech-exports $>$.

301 (2) (a), (b) of Law No. 21/1992 Coll., on Banks. 
It is possible to predict other complicated situations involving increased costs for Islamic banks that could become quite atypically value added tax payers ${ }^{31}$. Also, in the case of a Murabaha contract including sale of consumer goods this time, the bank gets into the position of a businesseman and its client acts as a consumer to whom the goods are sold. As a consequence, this contract would be covered by strict liability for any defects in terms of the provision 2940 of Act No. 89/2012 Coll., New Civil Code, which implements the European directive on consumer protection in the case of defective products ${ }^{32}$ and the bank (supplier) would have to provide compensation for damages.

\subsubsection{Guaranteed returns and insurance of deposit claims}

Finally, within the meaning of the Czech banking regulation, accepting deposits from the public is an expression of the banking monopoly on this activity and an essential feature distinguishing the banks from other businesses. However, in the system of Islamic finance (Shiraka models of financing) are not allowed any guaranteed returns. On the contrary, the bank and its clients are sharing expected profit or possbile loss according to a predetermined ratio, and the result of a co-financed investment can never be determined in advance. This raises questions related on the one hand to fulfillment of the rule contained in 1 (2) (a) of Law No. 21/1992 Coll., on Banks, stating that deposit „constitutes an obligation of the bank to the depositor to repayment" and, more importantly, on the other hand to Sharia-compliance of the deposit insurance schemes.

The deposit insurance is a measure implemented in many countries to protect bank depositors even outside Europe (North America, many Asian countries etc.). This mechanism serves as an instrument of a financial system safety net that promotes financial stability and was introduced to the EU law by the directive on deposit guarantee schemes ${ }^{33}$ in 1994 . Nowadays the new directive from $2014^{34}$ requires all 28 member states to have a deposit guarantee scheme for $100 \%$ of the deposited amount, up to 100,000 Euro per person (article 6 of the directive), and the same coverage level should apply to all depositors regardless of whether a member state's currency is the Euro (article 20 of the preamble of the directive).

The EU legislation is encoded in section 41a and the following provisions of Law No. 21/1992 Coll., on Banks, stating that „insured shall be all claims arising from deposits, including interest accrued, held in the Czech currency or in a foreign currency, registered as credit balances on accounts or deposit books or evidenced by

31 Act No. 235/2004 Coll., on Value Added Tax.

32 Council Directive 85/374/EEC of 25 July 1985 on the approximation of the laws, regulations and administrative provisions of the Member States concerning liability for defective.

33 Directive 94/19/EC of the European Parliament and of the Council of 30 May 1994 on deposit-guarantee schemes.

34 Directive 2014/49/EU of the European Parliament and of the Council of 16 April 2014 on deposit guarantee schemes. 
a certificate of deposit". This act also provides the legal basis for the establishment of the Deposit Insurance Fund into which banks shall contribute (its sources consist mainly from contributions from the banks, that is 0.04 percent of the average volume of insured deposit claims for the relevant calendar quarter according to 41c (6)). In accordance with provision 41d (1) compensation for an insured deposit claim shall be paid from the Fund to an eligible person after the Fund receives notification in writing from the $\mathrm{CNB}$ that the bank is unable to meet its commitments to eligible persons under the legal and contractual conditions.

But again, such a deposit guarantee scheme is not a Sharia-compliant system. Participation in the deposit-claims insurance scheme according to the EU principles of deposit guarantee cannot be considered by any means to conform with Sharia that prohibits any kind of returns to be previously guaranteed based on the principle „no risk, no gain“. Islamic bank as the fund manager that invests the depositors' money has no legal obligation (in the sense of Islamic law) to return the full value to its depositors. This is also factually impossible, because one cannot predict with absolute certainty the success of any risky investment that may result in loss or profit. The primary raison dêtre of the Islamic banking principles is that the depositors, banks and financed clients should share their profits and potential losses in the typically preferred (and more risky) Shiraka models.

Unfortunately the EU member states shall ensure that the deposits are protected and make it binding for all banks on their territories. As a consequence, the Act No. 21/1992 Coll., on Banks, is penalizing non-participation in the deposit insurance system as an administrative offence based on 36e (5) (f), that means if a bank fails to participate in the deposit-claims insurance scheme or to contribute to the Deposit Insurance Fund to the extent laid down in the Act.

The situation described above was resolved in the UK when licensing the oldest Islamic bank in the EU, the Islamic Bank of Britain (today Masraf Al Rayan $^{35}$ ). Actually, the British Financial Services Authority ${ }^{36}$ did not accept a Sharia-compliant concept for a deposit, and in the course of its licensing procedure, the Islamic Bank of Britain fully agreed to the concept of a deposit entitling the depositor to a full refund of the deposit and is complying with the obligations under the EU directive to take part in the deposit guarantee scheme into which it also makes contributions. The Islamic Bank of Britain's deposit contracts comprise a section stating that if the pool of funds returns a loss, the bank will, in line with the UK banking regulations and policy, offer to make good the depositor's loss and the depositor will be entitled to the deposited resources to their full

35 ATKIN, Joanne. Masraf Al Rayan acquires Islamic Bank of Britain [online]. Mortgagefinancegazette.com, c2014 [24.10.2015]. Accessible from WWW: <http://www.mortgagefinancegazette.com/islamic-finance/masraf-al-rayan-acquires-islamic-bank-of-britain/>.

36 The FSA was later on abolished with effect from 1 April 2013 due to its failures during the financial crisis and its responsibilities were then split between two new agencies: the Financial Conduct Authority and the Prudential Regulation Authority of the Bank of England according to the Financial Services Act 2012. 
extent. Nevertheless, the depositor is entitled to refuse this offer, and the Sharia Supervisory Board also advises that a depositor who accepts the offer by the Islamic bank to redress any shortfall is not acting in a Sharia-compliant way. ${ }^{37}$

In this way, the Islamic banks operating in Britain are regulated „under the general powers" based on the principle of "no obstacles, but no special favours ${ }^{\text {“ } 38}$. Entitlement to the deposited resources to their full extent is an individual right and constitutes no obligation. In addition, the funds accumulated in the British Financial Services Compensation Scheme are created mostly by conventional banks so that clients of Islamic banks should not even voluntarily ask for them. Nevertheless, this changes nothing on the fact that Islamic banks operating in the UK have no regulatory exception. In order to offer their services on the British market they had to adapt to the EU regulatory regime and realize some doctrinal concessions such as participating in the deposit guarantee scheme that is inconsistent with the precepts of Islamic law.

\subsection{Czech Republic on the way to halalization of its banking industry?}

Examples from other European countries with developed financial systems like the UK, Luxemburg or most recently Germany are showing an increasing demand for Islamic financial services across Europe. And we also know that in the past few years legislation in the concerned states went through some regulatory changes (particularly in tax matters) with the arrival of this segment of financial services. The first Islamic bank to enter Germany's banking sector was Kuveyt Türk Bank at the beginning of $2015^{39}$ but already at the 2009 conference had expressed the then executive of Federal Financial Supervisory Authority (BaFin, the financial regulatory authority in Germany) his opinion on the overall conformity and readiness of the German regulatory environment to accomodate providers of the Islamic financial services. ${ }^{40}$

Though the Czech Republic is characterized by a similar legal system like Germany, following the example of its bigger neigbour and welcoming an Islamic bank in the short term in Prague would not be smooth and easy under the current legislation out of the reasons explained above. Moreover, I have seri-

37 KÕVE, Anu. Current and Savings Deposits in Conventional and Islamic Retail Banking in the EU [online]. juridicainternational.eu, c2011 [24.10.2015]. Accessible from WWW: $<$ http://www.juridicainternational.eu/index.php?id=14831>.

38 NETHERCOTT, Craig R; EISENBERG David M. Islamic finance: law and practice. Oxford: Oxford University Press, 2012, p. 56. ISBN 978-0-19-956694-5.

39 Erste islamische Bank erhält Lizenz in Deutschland [online]. welt.de, c2015 [24.10.2015]. Accessible from WWW: <http://www.welt.de/wirtschaft/article138673632/Erste-islamische-Bank-erhaelt-Lizenz-in-Deutschland.html>.

40 KASEBERCK, Patrick. Islamic Banking. Kritische Evaluierung zur Einschätzung der Tauglichkeit für den deutschen Markt [online]. grin.com, c2013 [24.10.2015]. Accessible from WWW: <http://www.grin.com/de/e-book/214062/islamic-banking-kritische-evaluierung-zur-einschaetzung-der-tauglichkeit>. 
ous doubts about the meaningfulness of preparing the Czech legal order for the Islamic finance practice even in the future, especially given the absence of a thorough evaluation of the market potential of Islamic banks in the Czech Republic. Another aspects might be the relatively aloof attitude of the Czech citizens towards Islam and Muslims in general, ${ }^{41}$ as well as growing popularity of political movements such as "We Don't Want Islam in the Czech Republic" of which supporters are actually at least five times higher than the estimated number of all Muslims living in the Czech Republic. ${ }^{42}$ Thus, it seems that in the near future no halalization of the Czech banking industry is on the agenda.

\section{Conclusion}

Effort has been made to provide an overview of the current global status of the Islamic finance industry that is no longer confined to the Arab Gulf countries because it proves to be successful even in Europe. Subseqently, I tried to offer an explanation of the basic special requirements (Halal, Riba, Gharar, Maysir, Shiraka, Sharia Supervisory Board) for Islamic banks both in terms of defining and describing these principles as well as giving examples of various types of Islamic banking products focusing on Murabaha and Mudaraba that were examined from the Czech legal point of view on the previous pages.

In the light of the Islamic banking principles the Czech legal structure appears to be quite inflexible making it difficult or even impossible to fully implement the Islamic banking doctrine. As discussed above, these problems are related first of all to the fundemantal feature of Islamic law as a non-state legal system, then particularly to the legal definition of deposits and loans in the Law No. 21/1992 Coll., on Banks, and thus presumably the non-fulfillment of the two main banking activities under the Czech banking license. Other issues are concerning some aspects of the consumer or tax law as well as Sharia-compliance of the deposit insurance schemes.

Yet the question remains whether it makes sense to adapt the regulatory environment for Islamic banking institutions following the example of some other European countries, especially when considering the absence of any prior thorough evaluation of the market potential of Islamic banks in the Czech Republic, as well as a relatively reserved attitude of the Czech citizens towards anything that has to do with Islam. Out of these reasons it rather appears that in the near future no halalization of the Czech banking industry will be on the agenda.

41 Czech News Agency. Poll: Two-thirds of Czechs afraid of Islam [online]. Praguepost, c2014 [24.10.2015]. Accessible from WWW: <http://www.praguepost.com/czech-news/39081poll-two-thirds-of-czechs-afraid-of-islam $>$.

42 Czech News Agency. Islamophobia on the rise [online]. Praguepost, c2014 [24.10.2015]. Accessible from WWW: <http://www.praguepost.com/czech-news/43563-islamophobiaon-the-rise>. 